\title{
Business Development Service Provider Organizations in Micro Entrepreneurship Development in Western Hill, Nepal
}

\author{
Bir Bahadur Karki \\ Lecturer, Faculty of Management, PN Campus, Pokhara \\ bbkarki@gmail.com
}

\begin{abstract}
Business Development Service Providers Organization (BDSPO) play vital role specially in Micro Entrepreneurship Development (MED) sectors. BDSPO provides various types of services such as skill oriented training, facilitates to establish enterprises, identify sources of raw materials and other equipments, establish market link etc. Major Activities of the BDSPOs includes social mobilization of potential micro entrepreneurs, formation of Micro Enterprise Group (MEG) formation, House-Hold (HH) survey and participants selection, conduct Entrepreneurship Development Training (EDT) programmes, provides skill training and appropriate technology support, help to establish marketing linkage and product promotion, need assessment of entrepreneurs, identify and provide scale up activities, facilitates micro credit accessibilities, facilitates to formation of cooperatives and product association, facilitation of construction of new Common Facility Centers (CFCS) and examine as well as assess the uses of existing technology. The main objective of MEDEP is "improve the socio economic status hardcore poor and non hard core poor people through Micro Enterprise". On the response of the question of how do entrepreneur rate the business supportive policies of the other agencies like BDSPOs, 32.5percent entrepreneurs felt that the business supportive policies of the other agencies supportive. By 35.6 percent respondents felt the supportive policies of the other agencies is less supportive. The researches try to examine of the change in self-confidence before participation in EDP and after EDP. Paired t-test between effectiveness before participation in EDP and after EDP has been conducted. This shows a statistically significant influence of EDP on confidence level.
\end{abstract}

Key Words: Baglung, BDSPOs, micro entrepreneurship, Parbat 


\section{Introduction}

Business Development Services (BDS) refers to any non-financial service used by an enterprise to assist its business functioning or growth, provided in a formal or informal manner. BDS, in a true sense, can help enterprises, reduce costs, improve efficiency, access new markets, increase sales, enhance productivity and grow.

Traditionally, donors and governments have intervened in BDS markets at the level of the BDS transaction: directly providing services to Small and Micro Enterprises (SMEs) via public BDS providers, or permanently subsidizing services delivered by other BDS providers. In this approach, donors and governments have tended to substitute for underdeveloped BDS markets, possibly crowding out existing or potential commercial suppliers of services. This traditional approach has failed to achieve high outreach (access to services by a large proportion of the targeted population of SMEs, since the number of SMEs served is limited by the amount of subsidies available. Institutional sustainability has been low, since programmmes often cease when public funds are exhausted. Lastly, the services provided have often had limited impact on enterprises because they have been designed and delivered with public and donor funds rather than responding to demand from SMEs.

The direct provision of Business Development Service (BDS) by the Government has been found to be costly and inefficient way to develop the MSE sector. Thus, new channels for the delivery of BDS need to be designed, where the role of the Government is more focused on policy development, programmes design, monitoring and assessment (ILO, 2000).

The needs of the MSE sector are quite diverse and require more basic training and financial support. Greater emphasis should be given to the development of marketing skills, as well as to the skills required for opportunity identification market research, business planning and financial management (ILO, J, 2000).

The best practices experienced in international level now point to a new, more effective approach to providing SMEs with business services: developing commercial markets for BDS. Donors and governments drive by the belief that the objectives of outreach and sustainability can only be achieved in well-developed markets for BDS, and not by direct provision of 
the BDS market development approach. This shifts the focus of public and donor intervention away from direct provision and subsidies at the level of the BDS transactions, toward the facilitation of a sustained increase in the demand and supply of services. In the market development approach, subsidization of transactions should be replaced by private payment for services. Programmes to develop BDS markets aim to address factors, which are limiting SMEs' purchase of the services they want, and /or endeavour to better exploit market opportunities for improving SMEs' access to, and use of the BDS they want. Considering the weaker state of SMEs and micro-enterprises in Nepal, there is a need for the adaptation of the two approaches for some more years for micro-enterprises and SMEs in Nepal to utilize BDS for enhancing their competitiveness.

Berger and Guillanmen (1996) stated that micro-entrepreneurs not only look access to credit but also to nonfinancial services, including marketing, training in basic business skills such as book-keeping, and technology transfer. The quality of training offered to micro-entrepreneurs is generally low. The provision of these services has so far been heavily dependent on grant resources, limiting their sustainability over time. Moreover, the lack of organization of the microenterprise sector makes it more costly to provide services to these businesses.

There were working number of Non-Government Organizations (NGOs) in both Parbat and Baglung districts and have performed as Business Development Service Providers Organizations (BDSPOs) in micro enterprise development sectors. Among them, Sustainable Enterprise Environment and Women Awareness Society (SEEWA), Parbat and Sustainable Approach on Natural Resource Management and Gender Awareness for Micro Enterprise (SANGAM) have been working for Micro Enterprise Development Programme (MEDEP) and play the role of BDSPO. The SEEWA has focused only one district i.e. Parbat district, but SANGAM has wide working field and extending its field area in other districts such as Myagdi, Baglung, Parbat, and Kaski district. Both organizations are NGO and nonprofit organization. In the initial phase of MEDEP programme, the MEDEP itself plays the role of a BDSPO in Parbat district such organizations at the time this programme was started. 
SEEWA was established in 2003/09/01 at Kusma, Parbat district (DMEGA Parbat, 2014). SANGAM is one of the BDSPO promoted by the MEDEP, a joint initiative of the United Nations Development Programme (UNDP)/ Nepal and Ministry of Industry. It was registered in 2006 at District Administration Office (DAO) Myagdi under the NGO registration act 1977 (DMEGA Baglung, 2014). BDSPOs are known as non-profitable and nongovernment organization.

The micro enterprise development program was implemented by SANGAM with financial support of MEDEP/ UNDP. This organization aims to provide support in the poverty reduction through micro enterprise development according to the demand-driven model of MEDEP. The organisation is dedicated to improve socio-economic condition of people through the promotion and development of micro entrepreneurs in Baglung and Parbat district in the creation and upgrading of existing MEs. SANGAM is working as a BDSPO in the field of micro-enterprise development and promotion sector since 2012 with support from MEDEP in Baglung district. SANGAM had been selected as a BDSPO through the bidding process of MEDEP for Myagdi, Baglung, Kaski, and Parbat district.

The overall objective of the BDSPO such as SANGAM is to improve livelihoods of pro-poor, women, disadvantaged people (Dalit and Indigenous nationalities) and youth through micro enterprise creation and development. More specifically the major objectives of the organization are included to identify of local resources for creation and development of micro entrepreneurs in selected VDCs of district, conduction of MEDEP's model orientation and Participatory Rural Appraisal (PRA) in selected VDCs for the creation and development of MEs, to facilitate and conduct Start and Improve Your Business (SIYB) training for potential or new micro entrepreneurs and technical and skill development training and provide technology support for based on their enterprise, to create new micro entrepreneurs at different location, conduction of following training and appropriate technology for existing MEs, continuous follow up the existing and sick entrepreneurs and business counseling, to support market and marketing in new micro entrepreneurs, to facilitate pre-cooperative management training and facilitate registration process, to facilitate and prepare proposal for construction of new common facility center (CFC) in 
different VDC or selected areas or Micro Enterprise Groups (MEGs) and Micro Enterprise Group Associations (MEGAs), to facilitate to prepare business plan and revise business plan, to facilitate formation of village enterprise development committee (VEDC), selection of potential VDCs for development of MEs and for creation of MEs through coordination with Board member of District Micro Enterprise Group Association (DMEGA) and District Enterprise Development Committee (DEDC) and stakeholders. Together with many other constraints, the malfunctioning of BDS markets in developing and underdeveloped economies is hindering the development of the enterprise sector. The low availability and quality of BDS for SMEs is one of the reasons that the outsourcing of 'non-core' business functions is still very limited. This is one of the factors seriously affecting the productivity and competitiveness of SMEs in underdeveloped and developing countries. The SANGAM and SEEWA adopted MEDEP model while implementing programme. According to MEDEP model, first of all it is necessary to do resource analysis and potential market for established resource based enterprise. The organization had used social map, well being ranking, seasonal calendar, resource map, mobility map, time trade, time line, diagram tools of PRA.

The current challenges is to raise the quality of training and technical assistance programme, the development of marketing schemes that expand micro-entrepreneurs access to more profitable segments of the market, assistance to comply with legal and regulatory procedures, promote sub-contracting arrangements with larger firms, and transfer of appropriate technologies to improve productivity, especially those that are environmentally sound. Main objective of the study is to explore role of business development service provider organizations (BDSPOs) in micro entrepreneurship development in Nepal specially in Parbat and Bagulng district. In addition, this paper tries to identify major activities BDSPOs and examines the effectiveness of BDSPOs in micro entrepreneurship development sectors.

\section{Data and Methods}

Micro enterprise development programmes was launched in Parbat and 
Baglung districts and BDSPOs were working in both districts effectively to enhance and support of micro enterprise. This is main reasons behinds why this two district are selected for the purpose of study. The study is based on descriptive cum analytical research approach. Data and information are collected through primary and secondary sources. Secondary data and information are obtained specially through annual reports of SEEWA, SANGAM and micro enterprise development programme (MEDEP). Primary data are collected through structured questionnaire, focus group discussion and personal interviews with micro entrepreneurs. Sample size of the study is 350 . Out of total sample size, 200 respondents and 150 respondents are taken from Parbat district and Baglung district respectively. Sample sizes are determined appropriate ratio on the basis of total numbers of enterprises existing in these districts. Convenience sample is used for data collection. For analysis of data some statistical tools are used. Percentage and chi-square test are used for data analysis.

\section{Result and Discussion}

\section{Major Activities of the BDSPOs}

In Nepalese context, there is found that BDSPOs have been performed primary or basic functions such as selection of potential entrepreneurs, creation of micro enterprise, provide basic training and skilled, counseling, facilitate to prepare business plan, technical support etc. Therefore, it is seemed that there is a little difference between major activities of BDSPOs in the developing country like Nepal and the activities in the developed country. To achieve objectives, both BDSPOs are involved to implement the following activities specially in micro enterprise development sector (SANGAM, 2014).

\section{i) Social Mobilization}

Conduction of various discussions, interaction and meeting for the selection of Village Development committee (VDC) for the creation of MEs against target objectives were conducted for the planning and implementation of program.

Orientation of MEDEP model is very necessary before launching the program in field level. From this program, they have informed all the villagers about the objective of program, model of programme, 
potential support, supporting criteria, types of support, resources of local level, potential market, etc. They were also discussed and sharing about the practice of program and kind of support in this area.

\section{ii) Micro Enterprise Group (MEG) formation}

Micro enterprise group formation is one of the most important tasks of social mobilization. Its helps to feel ownership, built own their capacity, saving practices, and leadership.

iii) House-Hold (HH) Survey and Participants Selection

BDSP did household survey to find out the per capita income of household and individual. They took many kinds of information such as total family members, livestock, agriculture production, wage earning and other income. If the PCl is less than NP Rs. 21230.00 then the programmes support to him/her. Likewise, they also examined the entrepreneurship character mapping with the help of Form B. In here, they mainly focused on entrepreneur's character like business knowledge, interest, investment, skill, enterprise environment, family support etc. If he/she got 150 or more score, then programme can support them.

They also examine existing micro entrepreneur in their or not, if they have, what type of micro enterprise run their / types of resources / uses of machinery equipments/ skills/ product/ market/problems/ challenges/possibilities, etc via form " $\mathrm{C}$ ". They examine local market status. They collect information export/ import status, market demand / possible sales product/ views of sellers/ consumers, etc via form " $D$ ".

They fill form E "for" collecting information about traditional skill in entire community, groups, used technology, possible enterprise, etc. Form " $F$ " for the analysis of available local resource.

\section{iv) Entrepreneurship Development Training (EDT)}

Entrepreneurship training is one of the major components of MEDEP model. It is also known as backbone of MEDEP model. Entrepreneurship training plays catalyst role for enterprise creation. When they found the potential entrepreneurs by PRA, HH survey and participants' selection, and then they conduct the $1^{\text {st }}$ part 
of entrepreneurship training i.e. SIYB Package. They conducted training of potential entrepreneurs (TOPE) and training of Starting entrepreneurs (TOSE). Normally, they conducted 1st package (ToPE/ ToSE) in 5 days. In this training they mainly focused about enterprise, selection of appropriate enterprise, family support, and business cycle, business plan through picture demonstration, brain storming, game module, practices, discussion and lecture method. After this training, participants are ready to do start the enterprise. Field staff (Enterprise Development Facilitators-EDFs) were mobilized to conduct SIYB training.

v) Skill training and appropriate technology support

In entrepreneurship training, potential entrepreneurs select their enterprise based on available resources, knowledge and skill, interest, potential market, rule and regulation of government, business plans, etc. When entrepreneurs' select their enterprise, they provide them technical skill training according to their needs so that they can easily run their enterprise. SANGAM had conducted different skill development training and provide different kinds of appropriate technology for the start of their enterprise.

vi) Marketing linkage and product promotion

Marketing is a one of the important tasks for the enterprise. They conduct different types of market related program, interaction programme, $B$ to $B$ interaction, exposure visit, and so on for the new micro entrepreneurs. Mostly market related program they conduct before skill development training. It helps them to know about enterprise which helps, it helps them first. SANGAM organized some marketing task, for new micro entrepreneurs who help to know about enterprise relate knowledge, skills, marketing information, experiences from others.

\section{vii) Need assessment}

There was found some entrepreneur are inactive and some are sick .They don't work yet due to various problems like lack of availability of raw materials, market related issues, lack of availability of appropriate technology, lack of access to Micro Finance Institutions (MFIs) easily, lack of interest, lack of proper knowledge and skill about own their 
enterprise, lack of information etc. SANGAM had analyzed and select existing and sick MEs for a scale up support and some MEs were beneficiaries.

\section{viii) Scale up activities}

They provide refresher training/ technologies support and other counseling support for active, inactive and sick Micro Enterprises (MEs) in all Rural Market Centers (RMCs). They conduct refresher training, technologies support and market linkage support for existing and sick MEs for expand/restart/continue/upgrade own their enterprise. After this training, they are encouraged to expand and continue their enterprise. They continuously follow them up after training. Business counseling monitoring and follow up activities carried out.

\section{ix. Micro Credit accessibilities}

The SANGAM coordinated different micro finance institute worked in both districts for micro credit for new and existing micro finance institute. It helps to micro entrepreneur to start enterprise and upgrade. The amount was provided to various enterprises such as pig-keeping, tailoring, poultry farming, photography, beekeeping, vegetable cultivation, and embroidery etc.

\section{$\mathrm{x})$ Cooperatives and product association formation}

Cooperative/product association is a very essential for the micro entrepreneurs for the saving, credit, advocacy for enterprise issues. So, they aware micro enterprise, MEGs, MEGA and so on, they facilitate pre cooperative management training and registration process. Pre-cooperative management training and facilitate registration process were provided to different entrepreneurs such as vegetable cultivation, poultry farming and beekeeping, and Allo processing, Lokta processing and apple processing in various $\mathrm{RMC} /$ VDCs.

\section{xi) Facilitation of Constructing New CFCs}

The SANGAM had facilitated to constructing some new Common Facility Center (CFC) in different VDCs and RMCs.

\section{xii) Existing technology}

They also collect data about technology which is supported by 
MEDEP through direct DMEGA; and SANGAM itself. They collect information about their use of existing technology. If they are not properly used, the reason condition is also collected. In the study area there are adopted various kinds of machine and equipments in micro enterprises to run enterprises smoothly and to increase productivity of the enterprises.

They examine the environmental before they conduct, start and improve your help business training. It helps us to know about status of environment in particular places, screening effect/impact of the particular enterprise.

SANGAM has been working in the area of micro enterprise creation and development since 2007 with the vision of establishing as a main business development support providing organization for development of efficient and self-reliance society by improving the economic and social status of the people through enterprise development.

The organization followed the Demand-driven Model of MEDEP to implement the program in field level. SANGAM had mobilized its Enterprise Development Facilitators (EDFs) in field level for implementing the program effectively. In planning phase, the project team consulted with District Micro Enterprise Group association (DMEGA) staff and board member, District Enterprise Development Committee (DEDC), and other organizations. The organization had coordinated with respective Village Development Committee (VDC) secretaries for effectively implementation, internalization of MEDEP in local level.

BDSPOs provide various kinds of machine, tools and equipments through financial and technical support of MEDEP/UNDEP. BDSPOs provides subsidies to purchase improved technology included such as beehive, gloves, net cap, machine, sewing machine, stamping, die, farma, photo printer, Madani, Sundera processing, stamping machine, cutting board machine, cutting machine (Aaro), weighting machine, drinker, feeder, drum, tunnel, pittal sprayer, seed, Tan, sewing machine, scissor, interlocked machine, plastic tunnel, Tripal, electrical fan, wielding machine, grinding, cutter, Bluwer, Reti, sprayer, Fiita, Dhaka Tan, Charkha, Saugat cupboard, plastic tunnel, steam machine, lee, Bluwar, grander machine, label, kittle, stove, cutter, glasses, solar dryer, chopper, seeler, plastic crate, bitter 
machine, crate, pig, feeder, chowmine, Hippu Tan, leg charkha, solar, water Ghatta, grander machine, Balti, Bata, Tripal, Tin, mini tailor machine, oil sprayer machine, etc. Various MEGs have got these types of support in both districts.

SANGAM facilitate and orient micro- entrepreneur, microentrepreneur groups and micro enterprise group association about steps of planning process in different MEG and MEGA. They also facilitate and encourage participating settlement level of planning, ward level of planning, and village development committee level of planning. Some ward level meetings allocated budget for existing micro enterprise and new creation too. The SANGAM also facilitate to formation of Village Enterprise Development Committees (VEDC).

\section{Business Supportive Policies of the Other Agencies like BDSPOs}

\section{Table 1}

Business supportive policies of other agencies like BDSPOs

\begin{tabular}{lrr}
\hline Particulars & N & \multicolumn{2}{c}{ Percent } \\
\hline Most Supportive & 22 & 6.1 \\
Supportive & 95 & 26.4 \\
Less Supportive & 128 & 35.6 \\
Very Less Supportive & 88 & 24.4 \\
Not Supportive & 27 & 7.5 \\
Total & 360 & 100.0 \\
\hline
\end{tabular}

Sources: Field Survey, 2015

On the response of the question of how do entrepreneur rate the business supportive policies of the other agencies, 6.1 percent entrepreneurs felt that the business supportive policies of the other agencies most supportive and 26.4 percent respondents felt that supportive. By 35.6 percent respondents felt the supportive policies of the other agencies is less supportive. Only 7.5 percent respondents felt that the business supportive policy of the other agencies is not supportive.

\section{Change in Self-confidence}

To know the level of self-confidence of entrepreneurs before and after starting the business, a few questions were asked to entrepreneurs. Questions were asked whether entrepreneurs possessed the capacity of 
self-confidence before and after starting the enterprise in the following subject: ability to put own interest to family, ability to put own say in family discuss, and ability to put own the center meeting.

\section{Table 2}

\section{Change in Self-confidence}

\begin{tabular}{|c|c|c|c|}
\hline \multicolumn{4}{|c|}{ Paired Samples Test } \\
\hline & $\mathrm{T}$ & Df & Sig. (2-tailed) \\
\hline Pair 1 & 17.632 & 359 & .000 \\
\hline
\end{tabular}

Sources: Field Survey

Paired t-test between effectiveness before participation in EDP and after EDP has been conducted. This shows a statistically significant influence of EDP on confidence level. The result revealed that $t=17.632$, at $=359$ with $p=0.000$.

\section{Conclusion}

Micro enterprise development program is implemented in different VDCs of Baglung and Parbat districts where there have been great potentialities of resources and targeted groups are largely situated. Based on availability of natural resources, market potentialities, need and interest of the local people, poverty status and presence of target groups; the different VDCs have been selected. SANGAM and SEEWA are performed their activities as a role of BDSPO. First one has covered broad area rather than second BDSPO. As per the demand-driven model and instructions of MEDEP, both BDSPOs have been involved to conduct various programmes of micro enterprise development. In Nepalese context, BDSPOs have been performed basic or primary functions for creation and development of micro enterprise particularly in rural and semi-urban areas. The study result shows that most of the micro entrepreneurs feel that the supporting programmes of BDSPOs are in satisfactory level. BDSPOs do not support directly to entrepreneurs, however as a member of MEG they felt that financial and technical support from the BDSPO is not significant. There is needed to improve the activities of BDSPOs as well as strengthening of these organizations for regular and effective service providers. Entrepreneurs feel that level of self-confidence 
increased after starting their enterprises or after participation in EDP rather than before.

\section{References}

Berger, M. \& Guillanmen, B. (1996). Microenterprise development in Latin America-A view from the Inter-American Development Bank. Small Enterprise Development Vol.7 No.3 September.

District Micro Enterprise Group Association (DMEGA), Parbat. (2014). Annual progress report, 2014. Submitted to Area Programme Support Office (APSO), regional office Pokhara, Micro Enterprise Development Programme (MEDEP)

District Micro Enterprise Group Association (DMEGA), Baglung. (2014). Annual progress report, 2014. Submitted to Area Programme Support Office (APSO), regional office Pokhara, Micro Enterprise Development Programme (MEDEP)

International Labour Organization. (ILO) (2000). Resolution concerning statistics of employment in the informal sector, adopted by the Fifteenth International Conference of Labour statisticians (January 1993), in Current International Recommendations on Labour Statistics. Geneva: ILO.

International Labour Organization (ILO). J, (2000). Micro and small enterprise development and poverty alleviation in Thailand Support Services for Policy Programme Development (SPPD). UNDP Project THA/99/003 Micro and Small Enterprises: Giants in employment and development report and recommendations East Asia multidisciplinary advisory team Bangkok, Thailand (CISBN 922-012069-0) June.

Sustainable Approach on Natural Resource Management and Gender Awareness for Micro Enterprise (SANGAM). (2014). Annual report 2014. Submitted to Area Programme Support Office (APSO), regional office Pokhara, Micro Enterprise Development Programme (MEDEP) 